\title{
Analysing Political Discourse: Toward a Cognitive Approach ${ }^{1}$
}

\author{
Christopher Hart \\ University of Hertfordshire \\ c.j.hart@herts.ac.uk
}

The critical study of political discourse has up until very recently rested solely within the domain of the social sciences. Working within a linguistics framework, Critical Discourse Analysis (CDA), in particular Fairclough (Fairclough 1989, 1995a, 1995b, 2001; Fairclough and Wodak 1997), has been heavily influenced by Foucault. ${ }^{2}$ The linguistic theory that CDA and critical linguistics especially (which CDA subsumes) has traditionally drawn upon is Halliday's Systemic-Functional Grammar, which is largely concerned with the function of language in the social structure ${ }^{3}$ (Fowler et al. 1979; Fowler 1991; Kress and Hodge 1979).

Chilton (2005a: 3) states that "CDA has tended to draw ... on social theory of a particular type and on linguistics of a particular type." It is my intention here to suggest that the

\footnotetext{
${ }^{1}$ Published as Hart, C. 2005. Analysing political discourse: Toward a cognitive approach. Critical Discourse Studies 2 (2): 189-194.

${ }^{2}$ The work of social theorists who have concerned themselves with discourse has provided one major theoretical ground for the CD analyst to tread. Amongst the most influential of these scholars is, of course, the French post-structuralist philosopher Foucault. The Marxist-influenced critical theory of the Frankfurt School, in particular that of Adorno and Horkheimer, followed by Habermas, also has provided a framework for CD analysts.

${ }^{3}$ For Halliday, the principle function of language is to represent people, objects, events, and states of affairs in the world and to express the speaker's attitude to these representations. He holds that "language is as it is because of its function in the social structure" (1973: 65).
} 
cognitive sciences offer ideas significant to the $\mathrm{CD}$ analyst and yet which are still to be appropriated by mainstream CDA - exceptions to this with various cognitive approaches are Chilton (1996, 2004, 2005a, 2005b), Chilton and Lakoff (1995), Lakoff (1991, 1996, 2003), O'Halloran (2003), van Dijk (1998, 2002), and to a lesser extent Dirven (2001) and Lee (1992). With a cognitive perspective a new methodology for the identification and analysis of linguistic manipulation (a principle objective of CDA) can be constructed, CDA perhaps becoming more revealing than at present and some of its existing claims better attested. This methodology is derived from research in two areas of cognitive science; cognitive linguistics and cognitive-evolutionary psychology. Cognitive linguistics itself is a framework for the analysis of language. In this context, then, cognitive linguistics provides a new framework for the analysis of political language specifically. Concepts in cognitive linguistics provide a tool-kit, as Halliday's Systemic Functional Grammar does for critical linguistics, for the identification and analysis of linguistic and psychological strategies for manipulation in political discourse. Furthermore, cognitive-evolutionary psychology raises hypotheses as to a particular kind of manipulative discourse - discourse in which information is detailed that may activate/exploit innate cognitive programmes. Let us now very sketchily consider the application of this methodology to one currently prevalent political issue, namely immigration.

Cognitive linguistics holds that there are certain image schemata which constitute the foundations of human reason (Lakoff and Johnson 1980, 1999; Johnson 1987; Lakoff 1987). Further, these schemata are said to be embodied. One such schema is that of CONTAINMENT. On the embodiment of the container concept, Johnson (1987: 21) states that "our encounter with containment and boundedness is one of the most pervasive features of our bodily experience." It is this concept on which the political discourse surrounding immigration is constructed. ${ }^{4}$ Our country is conceptualised as a container, where a container consists of three salient structures: an interior and an exterior defined by a boundary - the boundary element of a Container-Nation being its political borders. This schema is most obviously activated (in English) with the spatial prepositions in and

\footnotetext{
${ }^{4}$ It was also a defining underlying concept in Cold War discourse (see Chilton 1996).
} 
out, markers frequently used to describe the spatial relation between Trajector (TR) (person) and Landmark (LM) - (country). ${ }^{5}$

In conceptual metaphor theory (Lakoff and Johnson 1980, 1999) properties from the source domain, in our case the CONTAINER schema, are mapped onto the target domain. "The essence of metaphor is understanding and experiencing one thing in terms of another" (Lakoff and Johnson 1980: 5). In the more recent theory of conceptual blending, which, beginning with the notion of mental spaces (Fauconnier 1994) offers an explanation of dynamic cognitive phenomena such as metaphor (Fauconnier and Turner 1996, 2002; Fauconnier 1997), the blended space "inherits partial structure from the input spaces, and has emergent structure of its own" (Fauconnier and Turner 1996: 113). One consequence, or entailment, of the Container-Nation metaphor is that nations, like containers, are conceptualised as having limited space. Consider the example of immigration discourse below, which is taken from the UK Independence Party's official website: ${ }^{6}$

With the fourth largest economy in world, the UK is the very attractive destination for people seeking a better life. [1] The trouble is the UK is already full up. The average population density of England is twice that of Germany, four times that of the France, and twelve times that of the United States. [2] We are bursting at the seams. ${ }^{7}$ [my bold]

Sentences [1] and [2] highlighted in the above text nicely demonstrate the ContainerNation metaphor. In actual fact, the text (or rather the author of the text) is using the metaphor to justify the party's immigration policy. In [1] the nation is being

\footnotetext{
${ }^{5}$ Using these terms in describing spatial relations scenes I am following Langacker's Cognitive Grammar framework (Langacker 1987, 1991).

${ }^{6}$ The UK Independence Party are an extremely right-wing political party whose manifesto is largely centred around immigration policy. Though they remain a fringe party, their hard-line policy provides interesting linguistic examples for the CD analyst, whilst from a socio-political point of view, with antiimmigration attitudes rife amongst some in the UK and with such parties participating in a recent UK election so concentrated on the issue of immigration, their rhetoric is an obvious focus of attention for CDA.

${ }^{7}$ It should be noted that this text is reproduced verbatim from the source and the grammatical errors are not that of the present author. Accessed 01/06/2005 at

http://www.ukip.org/index.php?menu=fivefreedoms\&page=fivefreedoms3
} 
conceptualised as a non-specified container which is 'full up'. In [2] 'bursting at the seams' activates a clothing frame (on frames see Fillmore 1982), where items of clothing are conceptualised as containers (for example, 'I can't get into these jeans'). In this case the delimiting boundary element of the container (the 'seams') is conceptualised as being stretched beyond capacity. If, as the tenets of cognitive linguistics maintain, metaphor is a cognitive reasoning process rather than simply surface-level linguistic flare, then metaphor in political discourse is highly significant for the $\mathrm{CD}$ analyst. ${ }^{8}$ Another metaphor, for example, Nation as Cuisine, where immigration is a vital ingredient, would prompt for a wholly different conceptualisation, would have different emergent structure in blending theory terms, of nation and immigration. ${ }^{9}$

Hopefully I have demonstrated to the reader, all be it incompletely, one way in which cognitive linguistics can be utilised in the critical analysis of political discourse. I shall now turn to the second element of our cognitive methodology and aim to do the same for cognitive-evolutionary psychology.

Evolutionary psychologists view the mind as a mass of interconnected but distinct modular programs, each of which is "functionally responsible for solving a different adaptive problem" (Cosmides and Tooby 2000: 91) faced by our ancestors during the EEA. $^{10}$ One such program is the cheater-detection module (Cosmides and Tooby 1989). Starting from the posit that in social species in which cooperative or altruistic ${ }^{11}$ behaviour is practiced, individuals must guard against the risks of exploitation, which is damaging to one's inclusive fitness ${ }^{12}$, it is postulated that a cheater-detection module has evolved to detect these risks, leading to cognitive and behavioural processes to counter them. One

\footnotetext{
${ }^{8}$ Chilton (1996, 2005b), Chilton and Lakoff (1995), and Lakoff (1991, 1996, 2003) all apply metaphor theory in the critical analysis of political discourse but these works are seldom acknowledged in CDA texts. ${ }^{9}$ It should be noted that this metaphor also is open to exploitation. For example, immigration could be metaphorised as erroneous or even poisonous ingredients.

${ }^{10}$ The EEA is not a specified place or time. Rather, it is the "statistical composite of selection pressures that caused the genes underlying the design of an adaptation to increase in frequency until they became species-typical or stably persistent" (Cosmides and Tooby 2000: 97).

11 "An entity is said to be altruistic if it behaves in such a way as to increase another such entity's welfare at the expense of its own" (Dawkins 1989: 4).

${ }^{12}$ The number of one's own genes that appear in current and subsequent generations.
} 
form of exploitation would be non-reciprocation to altruistic behaviour, i.e., exploitation by individuals who take but give nothing in return.

If information likely to activate the cheater-detection module is detailed in the language of political actors, which members of the electorate take to be propositionally true, then such language, we might want to suggest, is manipulative. Consider an example taken from a speech given by the Conservative party leader in Telford during the 2005 UK election campaign ${ }^{13}$ :

Our asylum system is being abused - and with it Britain's generosity. Only two out of ten people who claim asylum in Britain today are genuine refugees. [my bold]

The words highlighted are all candidates for words which might activate the cheaterdetection module. 'Generosity' and 'abused' are terms clearly linked with altruism and exploitation. 'Claims' need to be verified for their authenticity or 'genuineness' and if they prove to be 'non-genuine' they are considered exploitative. If individuals come to hold through the processing of political discourse that they are being exploited by immigration, then their cheater-detection module may be activated, affecting their (political) decision-making processes and leading to anti-immigration attitudes.

I have very crudely described just one module of the mind hypothesised by cognitiveevolutionary psychology which, if activated through discourse, is of interest to CD analysts. Others might include, for example, fear systems and other emotion programs or a kin-protection module.

With a cognitive methodology it is hoped that CDA can both progress further as an academic discipline and, as an instrument with which to highlight social manipulation enacted through discourse, become more emancipatory. Perhaps, though, the most important contribution that its integration with cognitive science can make to CDA, as well, in fact, as to our understanding of the human language process, is an answer to the

\footnotetext{
${ }^{13}$ Accessed on 01/06/2005 at http://www.bbc.co.uk/1/hi/uk_politics/vote_2005/frontpage/4430453.stm
} 
most fundamental charge facing CDA: does discourse matter? Is CDA merely engaged in the observation of surface-level linguistic representation or does political rhetoric have Orwellian effects? And if so, can we give a cognitive account of how they are achieved, of the mental processes involved? It is worth exploring, with the most recent findings on cognitive processing and cognitive modelling, evidence for the link, in cognition, between discourse and conceptual representation, and between conceptual representation and other cognitive domains. Relevance Theory (Sperber and Wilson 1995), for example, demonstrates that inferences prompted by discourse form part of the meaning, that is, conceptual representation, constructed from discourse. Conceptual blending demonstrates, because processing is carried out in the blended space, that metaphors matter. The human capacity for stimulus-detached processing means that information acquired through discourse and stored in memory can activate other cognitive programmes. And neurological (neuroimaging) studies present evidence that language can activate the amygdala (Isenberg et al. 1999), the centre for the emotions in the brain. ${ }^{14}$ This all given, then certain language-use (discourse) could influence conceptualisation and cognition, manipulating the individual into a position of support for some policy.

It is not yet clear whether these suggestions can be substantiated or how they could be formulated to construct a complete and lucid cognitive model for meaningful appropriation in the critical analysis of political discourse. Here, rather than set about making definitive claims, it has been my intention only to open and invite dialogue and debate on the ideas presented, creating a possible avenue for future research.

\footnotetext{
${ }^{14}$ Emotion programmes facilitate decision making processes (Damasio 1994).
} 


\section{$\underline{\text { References }}$}

Chilton, P., (1996). Security Metaphors: Cold War Discourse from Containment to Common House. New York: Lang. (2004). Analysing Political Discourse: Theory and Practice. Routledge: London. (2005a). Missing links in mainstream CDA: Modules, blends and the critical instinct. In R. Wodak and P. Chilton (ed.), A New Agenda in (Critical) Discourse Analysis: Theory, Methodology and Interdisciplinarity. Amsterdam: John Benjamins. pp.19-52. (2005b). Manipulation, memes and metaphors: The case of Mein Kampf.' In L. de Saussure and P. Schulz (eds.), New Perspectives on Manipulation and Ideologies in the Twentieth Century. Amsterdam: John Benjamins. pp.15-44.

Chilton, P. and G. Lakoff, (1995). Foreign policy by metaphor. In C. Schaffner and A.I. Wenden (eds.), Language and Peace. Aldershot: Ashgate. pp.37-60.

Cosmides, L., and J. Tooby, (1989). The logic of social exchange: has natural selection shaped how humans reason? Studies with the Wason selection task. Cognition 31: 187-276. (2000). Evolutionary psychology and the emotions. In M. Lewis and M.J. Haviland-Jones (eds.), Handbook of Emotions ( $2^{\text {nd }} e d$.). New York: Guilford Press. pp. 91-115.

Damasio, A.R., (1994). Descartes' Error: Emotion, Reason, and the Human Brain. New York: G. P. Putnam's Sons.

Dawkins, R., (1989). The Selfish Gene $\left(2^{\text {nd }} e d.\right)$. Oxford: Oxford University Press.

Dirven, R., (ed.) (2001). Language and Ideology volume I: Theoretical Cognitive Approaches. Amsterdam: John Benjamins.

Fairclough, N., (1989). Language and Power. London: Longman. (1995a). Media Discourse. London: Edward Arnold. (1995b). Critical Discourse Analysis: the Critical Study of Language. London: Longman. (2001). Language and Power ( $2^{\text {nd }}$ ed.). London: Longman.

Fairclough, N. and R. Wodak, (1997). Critical discourse analysis. In T. van Dijk (ed.), Discourse as Social Interaction. Discourse Studies: A Multidisciplinary Introduction, vol. 2. London: Sage. pp. 258-284.

Fauconnier, G., (1994). Mental Spaces. Cambridge University Press: New York. (1997). Mappings in Thought and Language. Cambridge: Cambridge University Press. 
Fauconnier, G. and M. Turner, (1996). Blending as a central process of grammar. In A.E. Goldberg (ed.), Conceptual Structure, Discourse and Language. Stanford, California: CSLI Publications. pp. 113-130. (2002). The Way we Think: Conceptual Blending and the Mind's Hidden Complexities. New York: Basic Books.

Fillmore, C., (1982). 'Frame semantics' in the Linguistics Society of Korea (ed.), Linguistics in the Morning Calm. Seoul: Hanshin Publishing Co.

Fowler, R., (1991). Language in the News: Discourse and Ideology in the Press. London: Routledge.

Fowler, R., B. Hodge, G. Kress, (1979). Language and Control. London: Routledge and Kegan.

Halliday, M.A.K., (1973). Explorations in the Functions of Language. London: Edward Arnold. .

Isenberg, Silbersweig, Engelien, Emmerich, Malavade, Beattie, Leon, and Stern, (1999). Linguistic threat activates amygdale. Proc. Natl. Acad. Sci. USA 19: 1045610459.

Johsnon, M., (1987). The Body in the Mind: The Bodily Basis of Meaning, Imagination, and Reason. Chicago: University of Chicago Press.

Kress and Hodge, (1979). Language as Ideology. London: Routledge and Kegan Paul.

Lakoff, G., (1987). Women, Fire, and Dangerous Things: What Categories Reveal about the Mind. Chicago: University of Chicago Press. (1991). Metaphor in Politics: an Open Letter to the Internet from George Lakoff. http://philosophy.uoregon.edu/metaphor/lakoff-1.htm (1996). Moral Politics: What Conservatives Know that Liberals Don't. Chicago: University of Chicago Press. (2003). Metaphor and War, Again. http://www.alternet.org/story.html?StoryID=15414

Lakoff, G. and M. Johnson, (1980). Metaphors we Live by. Chicago: University of Chicago Press. (1999). Philosophy in the Flesh: the Embodied Mind and its Challenge to Western Thought. New York: Basic Books.

Langacker, R., (1987). Foundations of a Cognitive Grammar vol. I. Stanford, CA: Stanford University Press. (1991). Foundations of a Cognitive Grammar vol. II. Stanford, CA: Stanford University Press. 
Lee, D., (1992). Competing Discourses: Perspective and Ideology in Language. New York: Longman Publishing.

O’Halloran, K., (2003). Critical Discourse Analysis and Language Cognition. Edinburgh: Edinburgh University Press.

van Dijk, T., (1998). Ideology: An Interdisciplinary Approach. Sage. London. (2002). 'Ideology: political discourse and cognition' in P. Chilton and C. Schaffner (eds.), Politics as Text and Talk. Amsterdam: John Benjamins. pp. 203-238.

Sperber, D. and D. Wilson, (1995). Relevance Theory: Communication and Cognition $\left(2^{\text {nd }} e d.\right)$. Cornwall: Blackwell. 